\title{
Nexus between integrating technology readiness 2.0 index and students' e-library services adoption amid the COVID- 19 challenges: Implications based on the theory of planned behavior
}

\author{
Taufik Edi Rahmat \\ Indonesia \\ Saqlain Raza \\ SZABIST \\ Hasan Zahid \\ Iqra University \\ Jaffar Abbas ( $\sim$ dr.abbas.jaffar@outlook.com ) \\ Shanghai jiao Tong University \\ Fatimah Azzahraa Mohd Sobri \\ Universiti Utara Malaysia \\ Shehla Najib Sidiki \\ SZABIST
}

Fakultas Ekonomi dan Bisnis, Department of Economic and Business, Universitas Sultan Ageng Tirtayasa, Serang,

\section{Research Article}

Keywords: E-library services, Medical education, COVID-19, Smart partial least squares, Technology adoption

Posted Date: August 2nd, 2021

DOl: https://doi.org/10.21203/rs.3.rs-770218/v1

License: @ (i) This work is licensed under a Creative Commons Attribution 4.0 International License. Read Full License 


\section{Abstract \\ Background}

The advent of the pandemic COVID-19 has resulted in a global crisis that resulted in the closure of universities and educational institutions worldwide. This study aims to explore the determinants of students' intention towards e-library services usage amid the challenging time of the COVID-19 pandemic. This paper reviews the technology-oriented individual attitude based on four dimensions of the technology readiness 2.0 index factors, which affect medical students' perspectives.

\section{Materials and methods}

The authors provided a self-administered questionnaire to medical students to investigate their e-library adoption attitude during the COVID-19 crisis. The authors distributed 542 questionnaires, received 361 complete responses and analyzed the data through path modeling/partial least squares structural equations modeling technique (PLS-SEM) with the smart PLS software version 3.3.3. The structural equation-modelling tool permits the estimation of results.

\section{Results}

The main finding revealed that medical students have a positive and explicit approach to use the services available at the e-library. Technology use and online services helped students continue their educational needs in the advent of the current pandemic COVID-19. Attitude and subjective norms have significant influence and are strong predictors of intention. However, due to inadequate support for the government side, the perceived behavioural control has an insignificant impact on intention. This paper indicated one of the pioneers investigating the determinants of e-library adoption among medical students based on technology-oriented personality traits, employing the four dimensions of the technology readiness 2.0 index during the challenges of the COVID-19 outbreak.

\section{Conclusion}

The study's findings provide useful insight that offers valuable insights to implement specific strategies from the government officials to address medical students' uncertainties and increase the technology adoption amid the COVID19 pandemic in medical education for developing nations.

\section{Introduction}

The appearance of the contagious viral disease COVID-19 posed challenges in providing education at campuses, and pandemic caused disruptions to deliver face-to-face education worldwide. The COVID-19 outbreak has massively damaged many sectors, including the educational industry ${ }^{[1,21]}$. Educationists and experts have looked into new dynamics to embrace the innovative shift in the educational system, ranging from educational activities delivery mode to shift on new online digital solutions. This study analyses the problems, barriers, challenges and success parameters by using online digital service in Pakistan and examining the determinants of students' intention to adopt e-library services and online content choice amid the pandemic COVID-19 $[2,21,38]$. Although the exact origin of the virus COVID19 dangerous disease is unknown, the health experts identified the first patient with the COVID-19 disease in Wuhan in late December 2019. There were confirmed cases of the COVID-19 disease over 180.863 million with deaths 3.935 
million worldwide. However, over 166.143 million infected people recovered from the infectious virus, COVID-19, as of June 27,2021 , around the world ${ }^{[3,41]}$.

The learning process describes how to acquire new knowledge ${ }^{[1-4]}$, creative understanding, skills, attitudes, preferences, and behaviors ${ }^{[5-9]}$. It is explained that learning has attained a central position in the competitive world of academia and research. ${ }^{[10-12]}$ Human learns and accumulates knowledge during normal and crises ${ }^{[13-15]}$, social skills, and facts of the natural world through different approaches that make our lives better ${ }^{[16-18]}$. It is essential for learners since it is evident from our practical work that learning affects people's daily lives. ${ }^{[19]}$ There is a surfeit of options for learning, such as, libraries, experiences, discussions, and practices; however, in today's electronic world, ${ }^{[13,20,21]}$ the e-learning (computerbased learning) ecosystem is assimilating all stakeholders with procedures and the latest technology. ${ }^{[22-26]}$ Consistent with the e-learning approach, electronic-library is gaining attention in the current era, allowing all users to access wellmanaged knowledge repositories ${ }^{[27-32]}$.

Generally, terms such as an electronic library, digital library, and virtual library are interchangeable in a sense. ${ }^{[33-37]} \mathrm{E}-$ library is an essential source for gathering valuable information on preferred topics ${ }^{[38-40]}$. Besides, the users can access an e-library with some resources such as e-books, e-journals, and educational websites. These services are accessible for the users ${ }^{[41-44]}$ to embrace and acquire the knowledge related to their concerned topics ${ }^{[45-47]}$. Comparing the traditional library pattern with an e-library, usually, human capital, enough space, and operational resources are required for conventional libraries. Nevertheless, e-learning offers an open-ended and individualized approach to learn, attracts more students, and drops the price of learning and the cost of operational resources ${ }^{[48-51]}$.

During the COVID-19 pandemic, the educational intuitions have actively practiced the online mode of education, which has affected education provision at institutions in many ways ${ }^{[52-54]}$. The quality of knowledge transfer is being questioned when past literature exhibited ${ }^{[55]}$ that millions of learners encounter difficulties in learning process ${ }^{[56-59]}$. Knowledge sharing is a vital step in the learning process ${ }^{[60,61]}$. If the quality of knowledge transfer is at stake, how to address the situation is crucial ${ }^{[62]}$. Huynh ${ }^{[63]}$ suggests that, under extraordinary circumstances, e-library systems have become the need of the hour for a strategic and technical benefit to meet the educational requirements of, especially, medical students. E-library resolves the problem by providing the additional best learning option, consulting e-libraries databases such as e-books, e-journals, and online educational content ${ }^{[64]}$.

In 2003, the higher education commission initiated corporate social responsibility with the National Digital Library Program established the first national e-library of Pakistan to contribute to society ${ }^{[34,65-68]}$. It provides enormous opportunities for all students to access almost 75,000 e-books and 20,000 e-journals. ${ }^{[69-71]}$ The Pakistan Information Technology Board (PITB) has taken an incredible initiative to establish e-libraries across Punjab province, where thousands of individuals have access to 50,000 e-books, e-journals, e-lectures, and webinars. PITB (2018) mentions that around 60,000 students enjoyed free access to the e-library in the area. The COVID-19 outbreak has massively affected the learning process; however, educational institutions adopted protective measures for safety purposes ${ }^{\text {[72-75] }}$. From a focus on the future perspective, the higher education commission of Pakistan is uninterruptedly striving to offer access to e-libraries in the main cities of Pakistan to prevail the culture of e-learning ${ }^{[38]}$. It intends to stimulate ease of access to ample content in a well-managed structure.

In line with previous arguments, the adoption of e-library among medical students is central, but the influencing factors toward its adoption have yet to be deduced. Therefore, the study has employed the planned behavior theory (TPB) to explore students' intentions and determinants to avail of the e-library service. ${ }^{[76]}$ These services and facilities are vital for students' e-learning environment. This study postulates the behavioral beliefs' attitude decomposed by technology 
readiness 2.0 index', normative beliefs based on "subjective norms" and control beliefs "perceived behavioral control" that lead to the e-library adoption. This investigation enables the authorities and policymakers in Pakistan to understand the medical students' acceptance of e-learning technology. See Figure 1 for details.

\section{Materials And Methods}

This present study used a self-administered questionnaire to the target population of medical students to examine their e-library services adoption attitude in the advent of the pandemic COVID-19 in Pakistan. The investigators authors distributed 542 questionnaires through online survey from September to November 2020, and received 361 complete and valid feedback forms from the participants with response rate of $66.61 \%(361 / 542=66.61 \%)$. the investigators eliminated incomplete responses and included only 361 valid and complete forms. The path modeling/partial least squares structural equations modeling technique (PLS-SEM) with the smart PLS software version 3.3.3 was used for analysis. The structural equation-modelling tool permits the estimation of results. Based on the research as mentioned above framework, the study hypothesized the following guiding objectives of the research:

- The study provides empirical evidence of how technology readiness' optimism, innovativeness, insecurity, and discomfort' affect attitude

- The study empirically examines the research model of how attitude, subjective norms, and perceived behavioral control affect intention to use e-library.

\section{Study design}

This study is based on a deductive approach, it uses a self-administered questionnaire to collect data from the respondents, medical colleges, and university students by using online survey ${ }^{[77-79]}$ Social sciences and business management studies follow these procedures to draw the results ${ }^{[80-82]}$.

\section{Participants and sample size}

The study has employed an online cross-sectional survey to a targeted population of medical students enrolled in three major cities of Punjab, namely, Lahore, Multan, and Rawalpindi. There are twenty e-libraries have been established across Punjab (the focus cluster) of Pakistan. The study used the data collected from enrolled medical students in three major cities of Punjab for analysis purposes. The sample size of this study is 361 complete and valid responses of the medical students selected in this survey to draw the results.

\section{Survey tool}

The questionnaire consists of two parts, A and B. Part A consists of the respondent demographics such as age, gender, education level, and living area. ${ }^{[83]}$ Similarly, part B consists of 33 items regarding the issues under investigation. ${ }^{\left[{ }^{84]}\right.}$ The construct of the technology readiness 2.0 index (16 items) has been adapted from the study of Parasuraman and Colby [85]. In contrast, the constructs of attitude (four items), subjective norm (four items), perceived behavioral control (four items), and intention (five items) have been adapted from Zahid and Haji Din. All items are measured on a seven-point (7) Likert scale ${ }^{\text {[86-89] }}$. 


\section{Results}

In the pursuit of testing the theoretical model, this research applied the partial least squares structural equation modeling (PLS-SEM) method to analyze the data. The study examined and tested the hypotheses through the PLS-SEM technique. Scholars typically apply this tool in the areas of management sciences, ${ }^{[90-92]}$ social sciences, and others Henseler et al. ${ }^{[94]}$, Hair et al. ${ }^{[86-89]}$. See Figure 1 and Table 2 below.

\section{Measurement model}

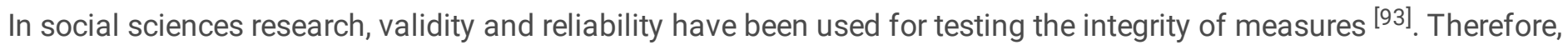
both (Cronbach's alpha and composite reliability) are reported here and met the threshold of 0.60 , as recommended by (Hair et al. 1998). See Table 1 below.

Tables 1. Factor loadings and reliability

\begin{tabular}{|lllll|}
\hline Items & \multicolumn{4}{l}{ Factor loadings and reliability } \\
\hline Variables & Cronbach's Alpha & RHP_A & CR & AVE \\
\hline Attitude & 0.808 & 0.82 & 0.873 & 0.634 \\
\hline Discomfort & 0.814 & 0.932 & 0.873 & 0.633 \\
\hline Innovativeness & 0.716 & 0.717 & 0.818 & 0.529 \\
\hline Insecurity & 0.774 & 0.806 & 0.851 & 0.589 \\
\hline Intention & 0.701 & 0.712 & 0.817 & 0.528 \\
\hline Optimism & 0.733 & 0.733 & 0.833 & 0.558 \\
\hline Perceived behavioural control & 0.866 & 0.885 & 0.894 & 0.681 \\
\hline Subjective norm & 0.714 & 0.727 & 0.822 & 0.536 \\
\hline
\end{tabular}

Note. $\mathrm{CR}=$ Composite reliability, AVE=Average variance extracted

Besides, the study examined the validity. The Heterotrait-Monotrait ratio was determined to test the validity within the context of the study. See Figure 3 and Table 2 for more details.

Table 2. Heterotrait-Monotrait Ratio 


\begin{tabular}{|c|c|c|c|c|c|c|c|c|}
\hline Variables & Attitude & Discomfort & Innovativeness & Insecurity & Intention & Optimism & PBC & $\mathrm{SN}$ \\
\hline Attitude & - & & & & & & & \\
\hline Discomfort & 0.155 & & & & & & & \\
\hline Innovativeness & 0.599 & 0.063 & & & & & & \\
\hline Insecurity & 0.178 & 0.47 & 0.114 & & & & & \\
\hline Intention & 0.718 & 0.15 & 0.682 & 0.171 & & & & \\
\hline Optimism & 0.313 & 0.073 & 0.491 & 0.056 & 0.363 & & & \\
\hline PBC & 0.061 & 0.279 & 0.132 & 0.358 & 0.081 & 0.071 & & \\
\hline SN & 0.416 & 0.074 & 0.473 & 0.135 & 0.517 & 0.302 & 0.082 & - \\
\hline
\end{tabular}

Note. $\mathrm{PBC}=$ Perceived behavioural control, $\mathrm{SN}=$ Subjective norm

\section{Structural model}

As per the above discussion, once the measurement model of the current study was established, considered reliable, and valid, the next step is to evaluate the structural model. In the structural assessment of the model, the techniques indicating "significance of path co-efficient $R^{2}$, effect size $\left(f^{2}\right)$, and predictive relevance $\left(Q^{2}\right)$ " proposed by a past study [86] are utilized. See Table 3.

Table 3. Summary of structural model

\begin{tabular}{|c|c|c|c|c|c|c|c|c|c|}
\hline Hypotheses & Relationships & $\begin{array}{l}\text { Path } \\
\text { coefficient }\end{array}$ & S.E. & t-test & $\begin{array}{l}p- \\
\text { value }\end{array}$ & Supported & $R^{2}$ & $Q^{2}$ & $f^{2}$ \\
\hline $\mathrm{H} 1$ & $\begin{array}{l}\text { Attitude >> } \\
\text { intention }\end{array}$ & 0.476 & 0.040 & 12.015 & 0.000 & Yes & 0.348 & 0.178 & 0.309 \\
\hline $\mathrm{H} 1 \mathrm{a}$ & $\begin{array}{l}\text { Optimism >> } \\
\text { attitude }\end{array}$ & 0.087 & 0.045 & 1.899 & 0.028 & Yes & & & 0.009 \\
\hline $\mathrm{H} 1 \mathrm{~b}$ & $\begin{array}{l}\text { Innovativeness >> } \\
\text { attitude }\end{array}$ & 0.455 & 0.045 & 10.065 & 0.000 & Yes & & & 0.246 \\
\hline $\mathrm{H} 1 \mathrm{c}$ & $\begin{array}{l}\text { Insecurity >> } \\
\text { Attitude }\end{array}$ & -0.073 & 0.043 & 1.692 & 0.047 & Yes & & & 0.006 \\
\hline $\mathrm{H} 1 \mathrm{~d}$ & $\begin{array}{l}\text { Discomfort >> } \\
\text { attitude }\end{array}$ & -0.090 & 0.042 & 2.190 & 0.016 & Yes & 0.269 & 0.159 & 0.010 \\
\hline $\mathrm{H} 2$ & $\begin{array}{l}\text { Subjective } \\
\text { norm } \gg>\text { intention }\end{array}$ & 0.221 & 0.047 & 4.999 & 0.000 & Yes & & & 0.067 \\
\hline H3 & $\begin{array}{l}\text { Perceived } \\
\text { behavioural } \\
\text { control >> } \\
\text { intention }\end{array}$ & 0.033 & 0.052 & 0.643 & 0.262 & No & & & 0.002 \\
\hline
\end{tabular}


Note. SE=Standard error

Next, the value of $R^{2}$ determines the explanatory power of the proposed model ${ }^{[94]}$. The outputs of the study have shown a substantial variance of $R^{2}=0.348$. Furthermore, Stone-Geisser's $Q^{2}$ was calculated using the blindfolding procedure to evaluate the predictive power of the structural model ${ }^{[94]}$, and the interpretation of the PLS path model of the study possessed sufficient predictive power ${ }^{[94,95]}$.

\section{Discussion}

The advent of the ongoing pandemic coronavirus has developed severe challenges for educational institutions in the environment of teachers-students and teaching learning, which caused changes to shift on online education through technology adoption to meet students' needs at higher and elementary educational institutions worldwide. The crisis has dramatically influenced the learning process between students and teachers at schools, colleges, and universities worldwide. Because of this abnormal and challenging situation, schools, colleges and universities encountered enormous challenges to provide physical education at campuses. The government closed educational institutions to reduce the virus spread. As a result, educational institutions, including universities, started their academic operations through online delivery using technological tools ${ }^{[96]}$. The spread of this deadly virus has posed disruptions for face-toface educational activities due to its severity to infect other people, and hospitals reported the first infected patient on December 16, 2019, in Wuhan city ${ }^{[97]}$.

The WHO office in China received a group of patients' data suffering from pneumonia symptoms in Wuhan on

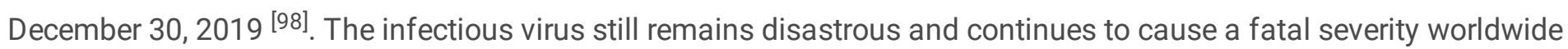
that led to the closure of colleges and universities due to the COVID-19 crisis. The disaster raised an inevitable demand for technological applications in the institutions for educational needs amid the COVID-19 to provide online classes and educational activities worldwide ${ }^{\text {[9-101] }}$. Accordingly, colleges and universities have initiated e-learning and online mode of education with the involvement of technology and media integration to fulfil students' needs in receiving lectures and educational content in the emergence of the COVID-19 crisis for the communication process to maintain educational activities. Universities and other educational institutions have launched e-services through innovative technology, social media forums, and higher education platforms to offer computer-mediated classes and online e-learning [102].

The study has empirically tested the direct effect of attitude (decomposed by technology readiness 2.0), subjective norm, and perceived behavioral control on intention to avail the e-library services among the medical students. In the study, the attitude was hypothesized to predict intention. The first hypothesis indicated that attitude $(\beta=0.476 ; p<0.05)$ significantly and positively influenced the intention. Therefore, this finding is consistent with the TPB that the higher the individual attitude, the higher the choice of using the services. In the second hypothesized relationship, the subjective norm would predict intention. The finding of this direct link indicated that subjective standard $(\beta=0.221 ; p<0.05)$ significantly and positively influences the intention. The result is aligned with the TPB approach.

In the third hypothesized relationship, perceived behavioural control did not lead to the intention. The result revealed that perceived behavioral control insignificantly influences the intention. The results exhibited that perceived behavioral control has an insignificant impact $(\beta=0.033 ; p>0.05)$ on an intention to avail the e-library services among the medical students. The possible explanation is that information technology knowledge among students is still not at the expected level as in the developed countries.

In this study, technology readiness 2.0's four dimensions were proven to get an inclusive idea of technology among medical students' attitudes toward the e-library services intention. $\mathrm{H} 1 \mathrm{a}$ and $\mathrm{H} 1 \mathrm{~b}$ predicted the positive and known contributor toward the technology. The current findings revealed that optimism $(\beta=0.087 ; p<0.05)$ and innovativeness 
$(\beta=0.455 ; p<0.05)$ have a significant and positive relationship with the Student's attitude toward the adoption of elibrary. Similarly, $\mathrm{H} 1 \mathrm{C}$ and $\mathrm{H} 1 \mathrm{~d}$ proposed a negative influence of technology, also known as an inhibitor towards the individual technology adoption. The present results of insecurity $(\beta=-0.073 ; p<0.05)$ and discomfort $(\beta=-0.090 ; p<$ 0.05) accepted the proposed hypotheses.

\section{Limitation and directions for future research}

The study is not beyond limitations though these limitations have addressed the future directions for the upcoming researchers. As an illustration, in the current study, data were collected using a quantitative approach. It will give future researchers a scholarly call to conduct qualitative research or mix-mode studies to get deeper insights into e-learning adoption. The cross-sectional research approach could be supported by the longitudinal research design to understand students' behavior toward e-learning. Finally, the study was conducted in Pakistan. Thus, future studies can be performed in other regions such as South Asian and Middle East countries to understand the phenomenon.

\section{Conclusion}

The present study investigated various antecedents of attitude (optimism, innovativeness, insecurity, and discomfort), subjective norms, and perceived behavioral control of e-library intention among the medical students. The conceptual model was formulated using the theory of planned behavior and the technology readiness 2.0 index. Out of seven hypotheses, only one hypothesis was rejected. Data were collected from the medical colleges and universities students used to visit e-library centers. A structural equation modeling technique (PLS-SEM) was used to test the hypotheses. The results indicated that optimism and innovativeness have a positive and insecurity and discomfort have a negative effect on the students' attitude. Besides, attitude and subjective norms significantly and positively influence and are strong predictors of intention, but perceived behavioral control does not significantly influence students' intention toward elibrary adoption.

\section{Declarations}

\section{Acknowledgment}

We are grateful to the district health officers for their support and assistance.

Financial support and sponsorship: NONE

Nil.

Conflicts of interest: There are no conflicts of interest.

\section{References}

1. Acheampong E, Agyemang FG. Enhancing academic library services provision in the distance learning environment with mobile technologies. J Acad Librariansh 2021;47:102279.

2. Pinho C, Franco M, Mendes L. Exploring the conditions of success in e-libraries in the higher education context through the lens of the social learning theory. Inf Manage 2020;57:103208. 
3. Subramaniam M, Hoffman KM, Davis K, Pitt C. Designing a connected learning toolkit for public library staff serving youth through the design-based implementation research method. Library \& Information Science Research. 2021;43 (1):101074.

4. Alrubaye H, Mkaouer MW, Khokhlov I, Reznik L, Ouni A, McGoff J. Learning to recommend third-party library migration opportunities at the API level. Applied Soft Computing. 2020;90:106140

5. Lau KSN, Lo P, Chiu DKW, et al. Library and learning experiences turned mobile: A comparative study between LIS and non-LIS students. The Journal of Academic Librarianship. 2020;46(2):102103.

6. Sherriff G, Benson D, Atwood GS. Practices, policies, and problems in the management of learning data: A survey of libraries' use of digital learning objects and the data they create. J Acad Librariansh 2019;45:102-9.

7. Hossain MA, Ferdousi R, Alhamid MF. Knowledge-driven machine learning-based framework for early-stage disease risk prediction in edge environment. J Parallel Distrib Comput 2020;146:25-34.

8. Dessì D, Osborne F, Reforgiato Recupero D, Buscaldi D, Motta E. Generating knowledge graphs by employing Natural Language Processing and Machine Learning techniques within the scholarly domain. Future Generation Computer Systems. 2021;116:253-264.

9. Mills K, Roper F, Cesare S. Accelerating student learning in communication and research skills: The adoption of adaptive learning technologies for scenario-based modules. In: Atkinson J, editor. Technology, Change and the Academic Library, Chandos Publishing, Oxford, UK; 2021. p. 75-84.

10. Zakharov A, Bondarenko O. Social status and social learning. Journal of Behavioral and Experimental Economics. 2021;90:101647.

11. Allison D, DeFrain E, Hitt BD, Tyler DC. Academic library as learning space and as collection: A learning commons' effects on collections and related resources and services. The Journal of Academic Librarianship. 2019;45(3):305314.

12. Li X, Zhu R, Ye H, Jiang C, Benslimane A. Metalnjury: Meta-learning framework for reusing the risk knowledge of different construction accidents. Safety Science. 2021;140:105315.

13. Shuja KH, Aqeel M, Jaffar A, Ahmed A. COVID-19 pandemic and impending global mental health implications. Psychiatr Danub 2020;32:32-5.

14. Shuja KH, Shahidullah, Aqeel M, Khan EA, Abbas J. Letter to highlight the effects of isolation on elderly during COVID-19 outbreak. Int J Geriatr Psychiatry 2020;35:1477-8.

15. Aqeel M, Abbas J, Shuja KH, et al. The Influence of Illness Perception, Anxiety and Depression Disorders on Students Mental Health during COVID-19 Outbreak in Pakistan: A Web-Based Cross-Sectional Survey. International Journal of Human Rights in Healthcare. 2021;14.1-20

16. Su Z, McDonnell D, Wen J, Kozak M, Abbas J, Šegalo S, et al. Mental health consequences of COVID-19 media coverage: The need for effective crisis communication practices. Global Health 2021;17:4.

17. Izuagbe R, Ibrahim NA, Ogiamien LO, et al. Effect of perceived ease of use on librarians' e-skills: Basis for library technology acceptance intention. Library \& Information Science Research. 2019;41(3):100969.

18. Jang M, Aavakare M, Nikou S, Kim S. The impact of literacy on intention to use digital technology for learning: $A$ comparative study of Korea and Finland. Telecommunications Policy. 2021;45(10):102154.

19. Lebni JY, Toghroli R, Abbas J, NeJhaddadgar N, Salahshoor MR, Mansourian M, et al. A study of internet addiction and its effects on mental health: A study based on Iranian University Students. J Educ Health Promot 2020;9:205.

20. Fattahi E, Solhi M, Abbas J, Kasmaei P, Rastaghi S, Pouresmaeil M, et al. Prioritization of needs among students of University of Medical Sciences: A needs assessment. J Educ Health Promot 2020;9:57.

21. Abbas J, Aman J, Nurunnabi M, Bano S. The Impact of Social Media on Learning Behavior for Sustainable Education: Evidence of Students from Selected Universities in Pakistan. Sustainability. 2019; 11:1683 
22. NeJhaddadgar N, Ziapour A, Zakkipour G, Abbas J, Abolfathi M, Shabani M. Effectiveness of telephone-based screening and triage during COVID-19 outbreak in the promoted primary healthcare system: a case study in Ardabil province, Iran. Z Gesundh Wiss. 2020;29:1-6.

23. Lebni JY, Toghroli R, Abbas J, Kianipour N, NeJhaddadgar N, Salahshoor MR, et al. Nurses' work-related quality of life and its influencing demographic factors at a public hospital in western Iran: A cross-sectional study. International Quarterly of Community Health Education 2020;41:272684X20972838.

24. Anjum MN, Xiuchun B, Abbas J, Shuguang Z, McMillan D. Analyzing predictors of customer satisfaction and assessment of retail banking problems in Pakistan. Cogent Business \& Management. 2017;4(1):1338842.

25. Su Z, McDonnell D, Cheshmehzangi A, Abbas J, Li X, Cai Y. The promise and perils of Unit 731 data to advance COVID-19 research. BMJ Global Health. 2021;6(5):e004772.

26. Furner M, Islam MZ, Li C-T. Knowledge discovery and visualisation framework using machine learning for music information retrieval from broadcast radio data. Expert Systems with Applications. 2021;182:115236.

27. Cidral WA, Oliveira T, Di Felice M, Aparicio M. E-learning success determinants: Brazilian empirical study. Computers \& Education. 2018;122:273-290.

28. Meskhi B, Ponomareva S, Ugnich E. E-learning in higher inclusive education: needs, opportunities and limitations. International Journal of Educational Management. 2019;33(3):424-437.

29. Atkinson J. Technology and change management in academic libraries: An overview and literature review. In: Atkinson J, editor. Technology, Change and the Academic Library. Oxford, UK.: Chandos Publishing; 2021. p. 11-32.

30. Trappey A, Trappey CV, Hsieh A. An intelligent patent recommender adopting machine learning approach for natural language processing: A case study for smart machinery technology mining. Technol Forecast Soc Change 2021;164:120511.

31. Anjaria K. Negation, and entropy: Effectual knowledge management equipment for learning organizations. Expert Syst Appl 2020;157:113497.

32. Islam MS, Kunifuji S, Hayama T, Miura M. Towards exploring a global scenario of e-learning in library and information science schools. The International Information \& Library Review. 2011; 43:15-22.

33. Al-Emran M, Mezhuyev V, Kamaludin A. Towards a conceptual model for examining the impact of knowledge management factors on mobile learning acceptance. Technol Soc 2020;61:101247.

34. Rafique GM, Mahmood K, Warraich NF, Rehman SU. Readiness for Online Learning during COVID-19 pandemic: A survey of Pakistani LIS students. The Journal of Academic Librarianship. 2021;47(3):102346.

35. Gray AC, Steel A, Adams J. Complementary medicine students' perceptions, perspectives, and experiences of learning technologies. A survey conducted in the US and Australia. Eur J Integr Med 2021;42:101304.

36. Xu F, Du JT. Examining differences and similarities between graduate and undergraduate students' user satisfaction with digital libraries. J Acad Librariansh 2019;45:102072.

37. Atkinson J, Reflections on technology, change, and academic libraries. In: Atkinson J, editor. Technology, Change and the Academic Librar. Oxford, UK. : Chandos Publishing; 2021. p. 185-93.

38. Maqsood A, Abbas J, Rehman G, Mubeen R. The paradigm shift for educational system continuance in the advent of COVID-19 pandemic: Mental health challenges and reflections. Current Research in Behavioral Sciences. 2021;2:100011.

39. Sun J, Yuan BZ. Development, and characteristic of digital library as a library branch. IERI Procedia 2012;2:12-7.

40. Raju J. Knowledge, and skills for the digital era academic library. J Acad Librariansh 2014;40:163-70.

41. Abbas J, Wang D, Su Z, Ziapour A. The role of social media in the advent of COVID-19 pandemic: Crisis management, mental health challenges and implications. Risk Manag Healthc Policy 2021;14:1917-32. 
42. Li S, Jiao F, Zhang Y, Xu X. Problems and Changes in Digital Libraries in the Age of Big Data From the Perspective of User Services. The Journal of Academic Librarianship. 2019;45(1):22-30.

43. Zakaria MS. Data visualization as a research support service in academic libraries: An investigation of world-class universities. J Acad Librariansh 2021;47:102397

44. Ocran TK, Underwood EP, Arthur PA. Strategies for successful implementation of mobile phone library services. J Acad Librariansh 2020;46:102174

45. Pinho C, Franco M, Mendes L. Exploring the conditions of success in e-libraries in the higher education context through the lens of the social learning theory. Information \& Management. 2020;57(4):103208.;

46. Azadi NA, Ziapour A, Lebni JY, Irandoost SF, Abbas J, Chaboksavar F. The effect of education based on health belief model on promoting preventive behaviors of hypertensive disease in staff of the Iran University of Medical Sciences. Arch Public Health 2021;79:69.

47. Moradi F, Tourani S, Ziapour A, Abbas J, Hematti M, Moghadam EJ, et al. Emotional Intelligence and Quality of Life in Elderly Diabetic Patients. Int Q Community Health Educ 2020;???:272684X20965811

48. Tarhini A, Masa'deh Re, Al-Busaidi KA, Mohammed AB, Maqableh M. Factors influencing students' adoption of elearning: a structural equation modeling approach. Journal of International Education in Business. 2017;10(2):164182.

49. Iqbal HM, Sohail S, Shahzad S. Learning and study strategies used by university students in Pakistan. Procedia Soc Behav Sci 2010;2:4717-21

50. Haider SJ. Perspectives on ... coping with change: Issues facing university libraries in Pakistan. J Acad Librariansh 2004;30:229-36

51. Cruz KFS, Mendes GHS, Lizarelli FL, Cauchick-Miguel PA. Antecedents and consequences of library service innovation: An investigation into Brazilian academic libraries. The Journal of Academic

Librarianship. 2020;46(6):102235.

52. Office IE. Acknowledgment to Reviewers of IJERPH in 2020. Int J Environ Res Public Health 2021;18:1259.

53. Abbas J, Mubeen R, lorember PT, Raza S, Mamirkulova G. Exploring the impact of COVID-19 on tourism: transformational potential and implications for a sustainable recovery of the travel and leisure industry. Current Research in Behavioral Sciences. 2021;2:100033.

54. Bangani S. The fake news wave: Academic libraries' battle against misinformation during COVID-19. J Acad Librariansh 2021;47: 102390.

55. Sakamoto T. E-Learning in Japanese Universities. Industry and Higher Education. 2016;17(6):397-404.

56. Yoosefi Lebni J, Abbas J, Moradi F, Salahshoor MR, Chaboksavar F, Irandoost SF, et al. How the COVID-19 pandemic effected economic, social, political, and cultural factors: A lesson from Iran. Int J Soc Psychiatry 2021;67:298-300.

57. Seufert S, Guggemos J, Sailer M. Technology-related knowledge, skills, and attitudes of pre- and in-service teachers: The current situation and emerging trends. Comput Human Behav 2021;115:106552.

58. Scuotto V, Beatrice O, Valentina C, Nicotra M, Di Gioia L, Farina Briamonte M. Uncovering the micro-foundations of knowledge sharing in open innovation partnerships: An intention-based perspective of technology transfer. Technological Forecasting and Social Change. 2020;152:119906.

59. Huang CE. Discovering the creative processes of students: Multi-way interactions among knowledge acquisition, sharing and learning environment. J Hosp Leis Sport Tour Educ 2020;26:100237.

60. Bouton E, Tal SB, Asterhan CS. Students, social network technology and learning in higher education: Visions of collaborative knowledge construction vs. the reality of knowledge sharing. Intern High Educ 2021;49:100787. 
61. Kwayu S, Abubakar M, Lal B. The influence of informal social media practices on knowledge sharing and work processes within organizations. Int J Inf Manage 2021;58:102280.

62. Abbasi S, Ayoob T, Malik A, Memon SI. Perceptions of students regarding E-learning during Covid-19 at a private medical college. Pak J Med Sci 2020;36:S57-61.

63. Huynh R. The role of E-learning in medical education. Acad Med 2017;92:430.

64. Hendal BA. Kuwait University faculty's use of electronic resources during the COVID-19 pandemic. Digital Library Perspectives. 2020;36(4):429-439.[?]

65. Abbas, J., Mahmood, S., Ali, H., Ali Raza, M., Ali, G., Aman, J., Bano, S., \& Nurunnabi, M.[ The effects of corporate social responsibility practices and environmental factors through a moderating role of social media marketing on sustainable performance of Firms' operating in Multan, Pakistan. Sustainability 2019; 11(12), 3434.

66. Rafique H, Alroobaea R, Munawar BA, Krichen M, Rubaiee S, Bashir AK. Do digital students show an inclination toward continuous use of academic library applications? A case study. The Journal of Academic Librarianship. 2021;47(2):102298.

67. Rafique H, Almagrabi AO, Shamim A, Anwar F, Bashir AK. Investigating the Acceptance of Mobile Library Applications with an Extended Technology Acceptance Model (TAM). Computers \& Education. 2020;145:103732.

68. Rafiq M, Batool SH, Ali AF, Ullah M. University libraries response to COVID-19 pandemic: A developing country perspective. The Journal of Academic Librarianship. 2021;47(1):102280.

69. Karim RA, Shakil AF. A research study about the importance of e-library for globalized learning among students at university level in Karachi, Pakistan. RADS J Soc Sci Bus Manage 2017;4:104-14.

70. Omotayo FO, Haliru A. Perception of task-technology fit of digital library among undergraduates in selected universities in Nigeria. J Acad Librariansh 2020;46:102097.

71. Ullah R, Richardson JTE, Malik RA, Farooq S. Perceptions of the learning environment, learning preferences, and approaches to studying among medical students in Pakistan. Studies in Educational Evaluation. 2016;50:62-70.

72. NeJhaddadgar N, Ziapour A, Abbas J, Mardi A, Zare M. Correlation between general health and sexual function in older women in an Iranian setting. J Educ Health Promot 2020;9:300.

73. Yoosefi Lebni J, Abbas J, Khorami F, Khosravi B, Jalali A, Ziapour A. Challenges facing women survivors of selfimmolation in the Kurdish Regions of Iran: A qualitative study. Front Psychiatry 2020;11:778.

74. Su Z, Wen J, Abbas J, McDonnell D, Cheshmehzangi A, Li X, et al. A race for a better understanding of COVID-19 vaccine non-adopters. Brain Behav Immun Health 2020;9:100159.

75. Shuja KH, Shahidullah, Aqeel M, Khan EA, Abbas J. Letter to highlight the effects of isolation on elderly during COVID-19 outbreak. Int J Geriatr Psychiatry 2020;35:1477-8.

76. Cox A, Brewster L. Library support for student mental health and well-being in the UK: Before and during the COVID19 pandemic. J Acad Librariansh 2020;46:102256.

77. Aman J, Abbas J, Mahmood S, Nurunnabi M, Bano S. The Influence of Islamic Religiosity on the Perceived SocioCultural Impact of Sustainable Tourism Development in Pakistan: A Structural Equation Modeling Approach. Sustainability. 2019;11(11):3039.

78. Mamirkulova G, Mi J, Abbas J, Mahmood S, Mubeen R, Ziapour A. New Silk Road infrastructure opportunities in developing tourism environment for residents better quality of life. Global Ecology and Conservation. 2020; 24:e01194.

79. Tor SF. Probing the effect of library staff' discussions at duty posts on graduate students' research activities: Evidence from a Nigerian university library. J Acad Librariansh 2021;47:102278. 
80. Abbas J, Aqeel M, Abbas J, Shaher B, A J, Sundas J, et al. The moderating role of social support for marital adjustment, depression, anxiety, and stress: Evidence from Pakistani working and nonworking women. J Affect Disord 2019;244:231-8.

81. Local Burden of Disease HIV Collaborators. Mapping subnational HIV mortality in six Latin American countries with incomplete vital registration systems. BMC Med 2021;19:4.

82. Toqeer S, Aqeel M, Shuja KH, Bibi A, Abbas J. Attachment Styles, Facebook Addiction, Dissociation and Alexithymia in University Students; A Mediational Model. Nature-Nurture Journal of Psychology. 2021;1(1):28-37.

83. Mubeen R, Han D, Abbas J, Hussain I. The Effects of Market Competition, Capital Structure, and CEO Duality on Firm Performance: A Mediation Analysis by Incorporating the GMM Model Technique. Sustainability. 2020;12(8):3480.

84. Hussain T, Abbas J, Wei Z, Ahmad S, Xuehao B, Gaoli Z. Impact of Urban Village Disamenity on Neighboring Residential Properties: Empirical Evidence from Nanjing through Hedonic Pricing Model Appraisal. Journal of Urban Planning and Development. 2021;147(1):04020055.

1. Parasuraman A, Colby CL. An Updated and Streamlined Technology Readiness Index. Journal of Service Research. 2014;18 (1):59-74.

2. Hair Jr JF, Hult GTM, Ringle C, Sarstedt M. A primer on partial least squares structural equation modeling (PLSSEM): Sage publications; 2016. A Primer on Partial Least Squares Structural Equation Modeling (PLS-SEM), Newbury Park, California, USA. Sage Publications; 2016.

3. F. Hair Jr J, Sarstedt M, Hopkins L, G. Kuppelwieser V. Partial least squares structural equation modeling (PLS-SEM). European Business Review. 2014;26(2):106-121.

4. Zahid H, Haji Din B. Determinants of intention to adopt E-government services in Pakistan: An imperative for sustainable development. Resources 2019;8:128.

5. Zaman U, Zahid H, Habibullah MS, Din BH, Wright LT. Adoption of Big Data Analytics (BDA) Technologies in Disaster Management: A Decomposed Theory of Planned Behavior (DTPB) Approach. Cogent Business \& Management. 2021;8(1):1880253.

6. Hair JF, Sarstedt M, Ringle CM, Gudergan SP. Advanced Issues in Partial Least Squares Structural Equation Modeling: SAGE Publications; 2017, USA, SAGE Publications

7. Abbas, J., Raza, S., Nurunnabi, M., Minai, M. S., \& Bano, S. The impact of entrepreneurial business networks on firms' performance through a mediating role of dynamic capabilities. Sustainability 2019;11:3006.

8. Aman J, Abbas J, Nurunnabi M, Bano S. The Relationship of Religiosity and Marital Satisfaction: The Role of Religious Commitment and Practices on Marital Satisfaction Among Pakistani Respondents. Behavioral Sciences. 2019;9(3):30.

9. Moradi F, Toghroli R, Abbas J, Ziapour A, Lebni JY, Aghili A, et al. Hospital managers' skills required and onward challenges: A qualitative study. J Educ Health Promot 2020;9:228.

10. Henseler J, Ringle CM, Sinkovics RR. The use of partial least squares path modeling in international marketing. In: New Challenges to International Marketing. England: Emerald Group Publishing Limited; 2009.

11. Geisser S. A predictive approach to the random effect model. Biometrika 1974;61:101-7.

12. Sobaih AEE, Hasanein AM, Abu Elnasr AE. Responses to COVID-19 in Higher Education: Social Media Usage for Sustaining Formal Academic Communication in Developing Countries. Sustainability. 2020;12(16):6520.

13. Huang C, Wang Y, Li X, et al. Clinical features of patients infected with 2019 novel coronavirus in Wuhan, China. Lancet. 2020;395(10223):497-506.

14. Guarner J. Three Emerging Coronaviruses in Two Decades. Am J Clin Pathol. 2020;153(4):420-421.

Page 13/16 
15. Mailizar M, Almanthari A, Maulina S, Bruce S. Secondary School Mathematics Teachers' Views on E-learning Implementation Barriers during the COVID-19 Pandemic: The Case of Indonesia. Eurasia Journal of Mathematics, Science and Technology Education. 2020;16(7):em1860.

16. Kerres M. Against All Odds: Education in Germany Coping with Covid-19. Postdigital Science and Education. 2020;2(3):690-694.

17. Wang CJ, Ng CY, Brook RH. Response to COVID-19 in Taiwan: Big Data Analytics, New Technology, and Proactive Testing. JAMA. 2020;323(14):1341-1342.

18. Al-Rahmi WM, Alzahrani Al, Yahaya N, Alalwan N, Kamin YB. Digital Communication: Information and Communication Technology (ICT) Usage for Education Sustainability. Sustainability. 2020;12(12):5052.

\section{Figures}

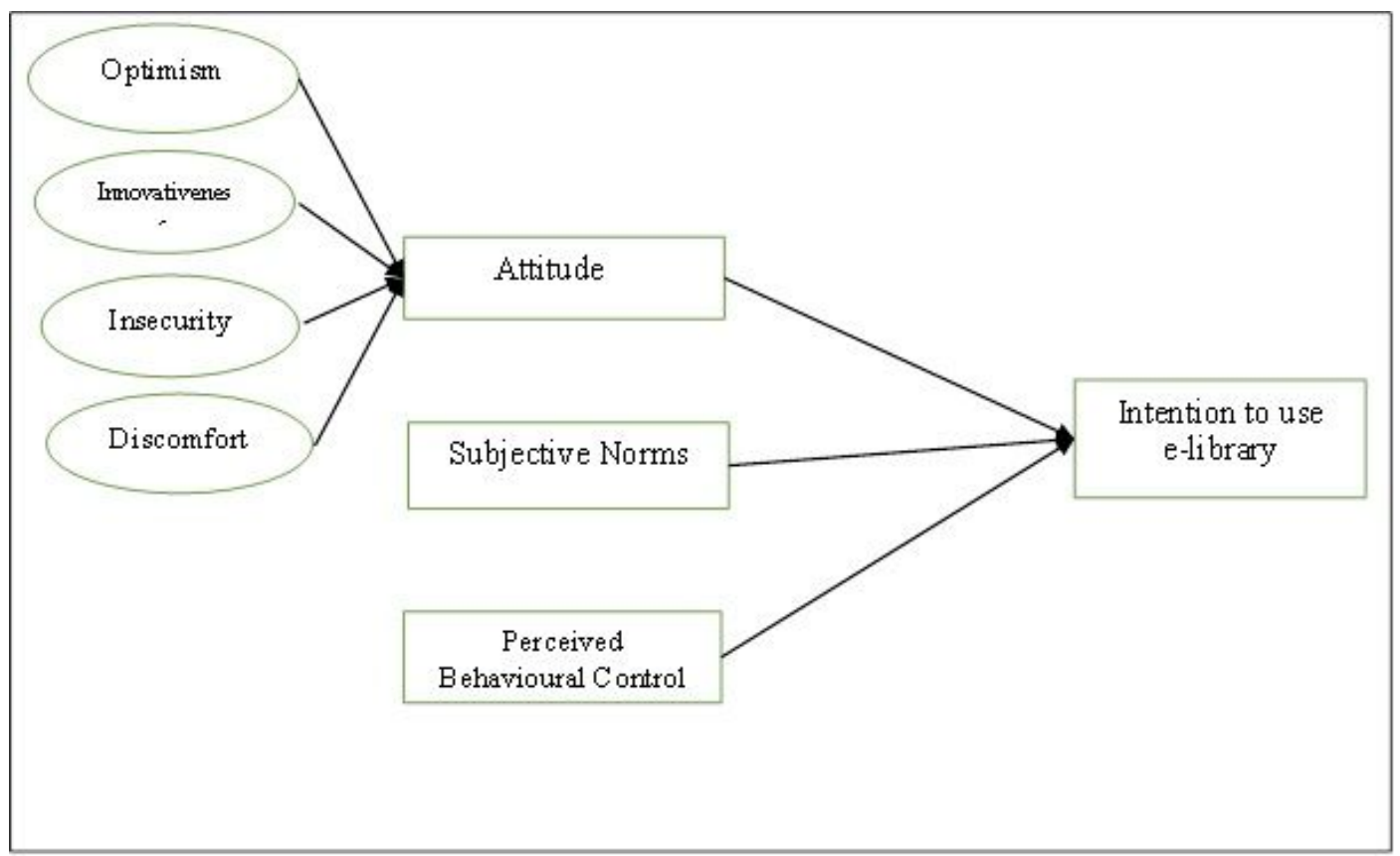

\section{Figure 1}

Research Framework. Note. Fig.1 shows the proposed study model with its variables. 


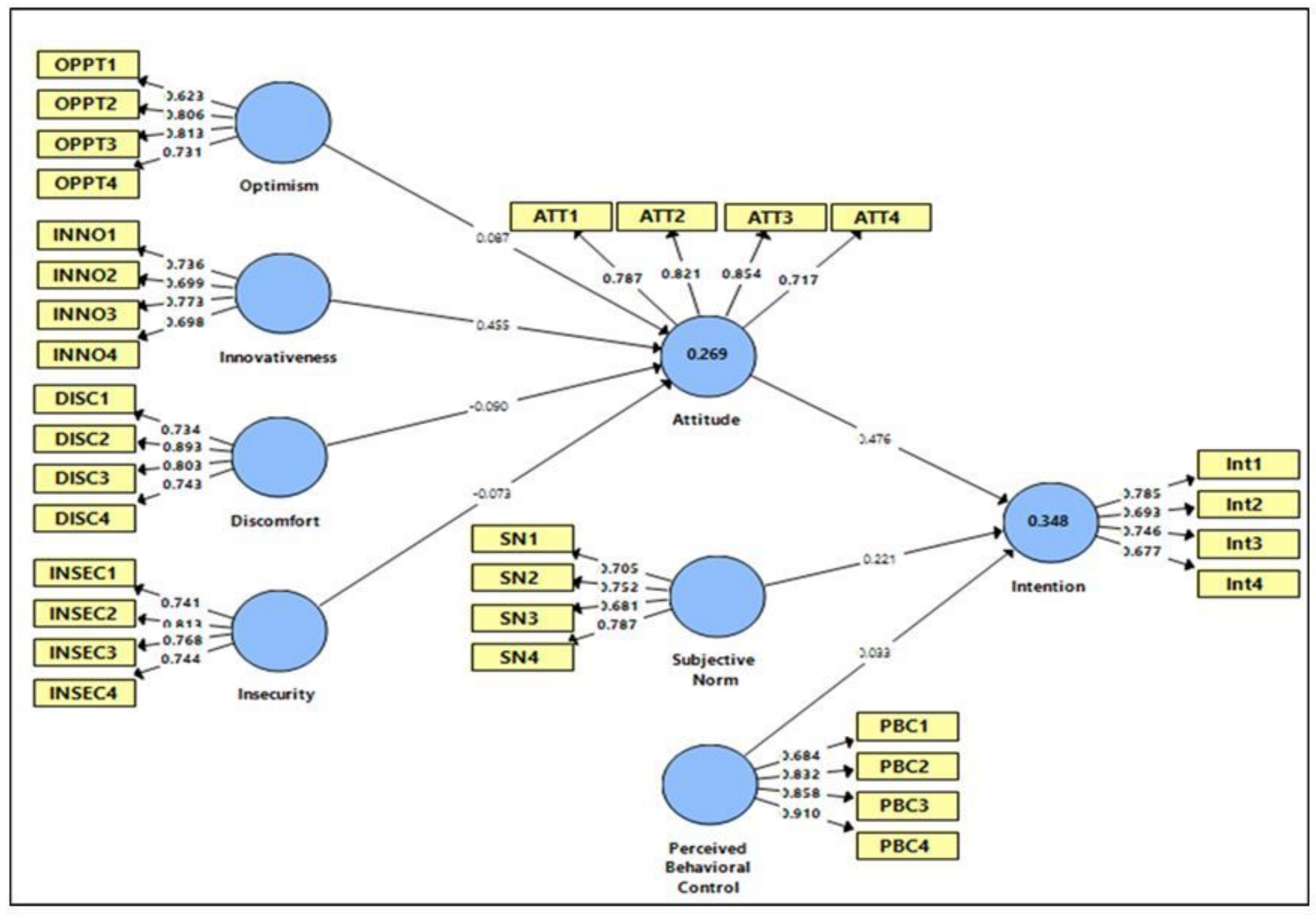

Figure 2

Measurement model 


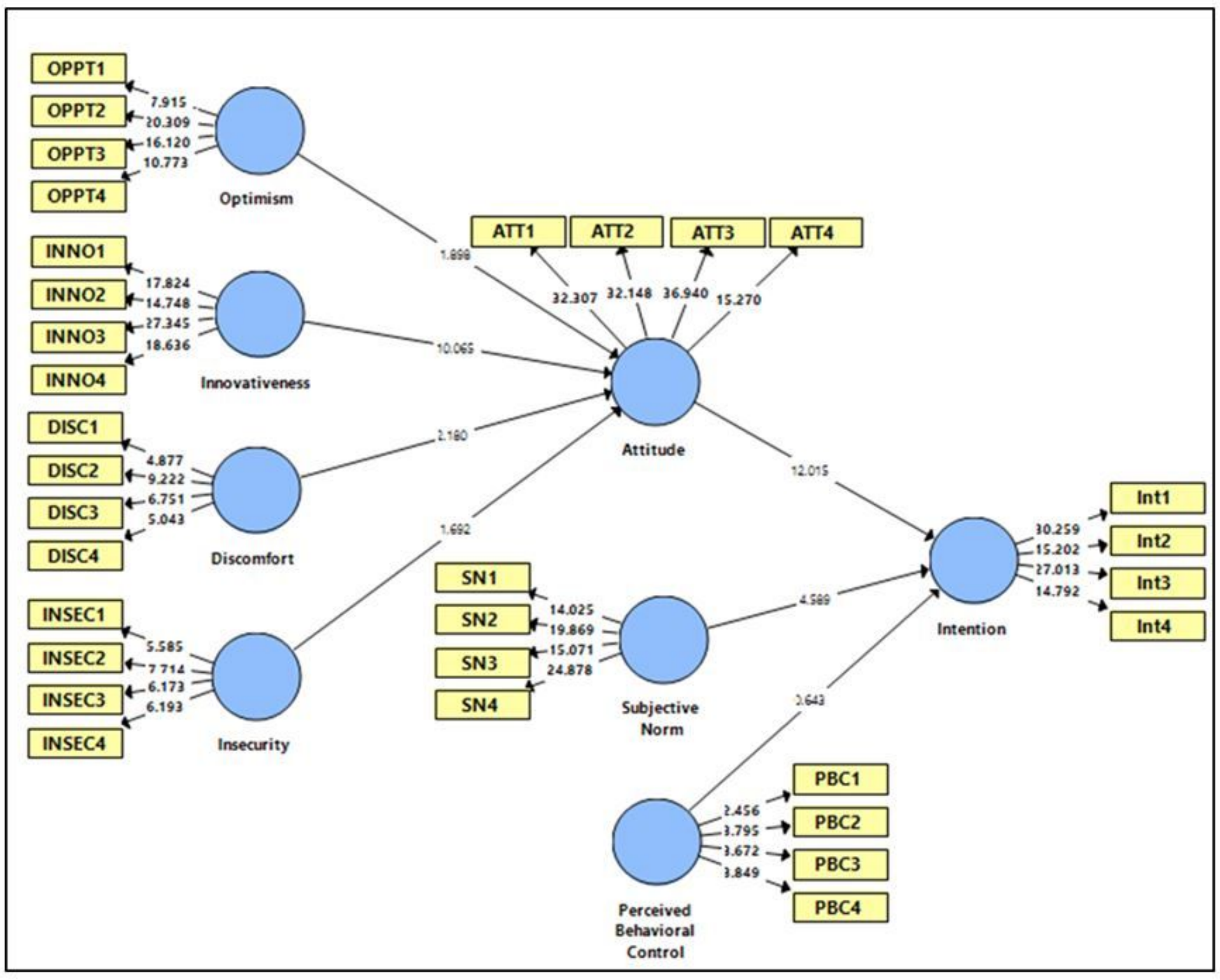

Figure 3

Structural model 